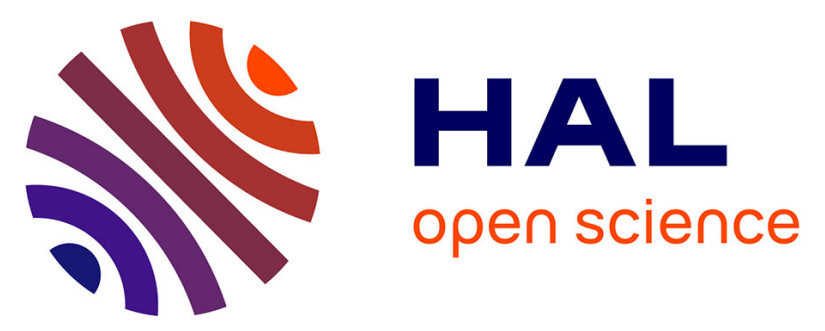

\title{
Land-use effects on the distribution of soil organic carbon within particle-size fractions of volcanic soils in the Transmexican Volcanic Belt (Mexico)
}

S. Covaleda, J.F. Gallardo, F. Garcia-Oliva, H. Kirchmann, C. Prat, M. Bravo, J. Etchevers

\section{To cite this version:}

S. Covaleda, J.F. Gallardo, F. Garcia-Oliva, H. Kirchmann, C. Prat, et al.. Land-use effects on the distribution of soil organic carbon within particle-size fractions of volcanic soils in the Transmexican Volcanic Belt (Mexico). Soil Use and Management, 2011, 27 (2), pp.186-194. 10.1111/j.14752743.2011.00341.x . insu-00648128

\section{HAL Id: insu-00648128 \\ https://hal-insu.archives-ouvertes.fr/insu-00648128}

Submitted on 11 Mar 2021

HAL is a multi-disciplinary open access archive for the deposit and dissemination of scientific research documents, whether they are published or not. The documents may come from teaching and research institutions in France or abroad, or from public or private research centers.
L'archive ouverte pluridisciplinaire HAL, est destinée au dépôt et à la diffusion de documents scientifiques de niveau recherche, publiés ou non, émanant des établissements d'enseignement et de recherche français ou étrangers, des laboratoires publics ou privés. 


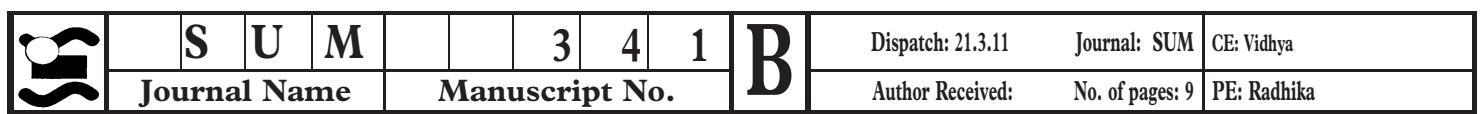

\title{
Land-use effects on the distribution of soil organic carbon within particle-size fractions of volcanic soils in the Transmexican Volcanic Belt (Mexico)
}

\author{
S. Covaleda ${ }^{1}$, J. F. Gallardo ${ }^{1}, F \cdot$ García-Oliva $^{2}, \mathrm{H} \cdot \mathrm{K}_{\text {irchmann }}{ }^{3}, \mathrm{C} \cdot \mathrm{Prat}^{4}, \mathrm{M} \cdot \mathrm{Bravo}^{5} \&$ \\ J. D. ETCHEVERS ${ }^{6}$ \\ ${ }^{1}$ C. S. I. C., IRNASa, Aptado 257, Salamanca 37071, Spain, ${ }^{2}$ Universidad Nacional Autónoma de México, Centro de \\ Investigaciones en Ecosistemas, AP 27-3. Santa Maria de Guido, Morelia 58090, Michoacán, México, ${ }^{3}$ Swedish University of \\ Agricultural Sciences, Department of Soil Sciences, Box 7014, 75007 Uppsala, Sweden, ${ }^{4}$ IRD-LTHE (Laboratoire d'Etude des \\ Transferts en Hydrologie et Environnement, BP 53, 38041 Grenoble, Cedex 9, France, ${ }^{5}$ Campo Experimental Uruapan, I.N.I.F.A.P. \\ Av. Latinoamericana 1101, Col. Revolución, CP 60150, Uruapan, Michoacán, México, and ${ }^{6}$ Colegio de Postgraduados, Laboratorio \\ 1 de Fertilidad de Suelos, Montecillo 56230, Edo. de México, México
}

\begin{abstract}
2 The aim of this study was to determine the effect of land-use and forest cover depletion on the distribution of soil organic carbon (SOC) within particle-size fractions in a volcanic soil. Emphasis was given to the thermal properties of soils. Six representative sites in Mexico were selected in an area dominated by Andosols: a grassland site, four forested sites with different levels of degradation and an agricultural site. Soils were fractionated using ultrasonic energy until complete dispersion was achieved. The particle-size fractions were coarse sand, fine sand, silt, clay and particulate organic matter from the coarse sand sized fraction (POM-CS) and fine sand (POM-FS). Soil organic carbon decreased by $70 \%$ after forest conversion to cropland and long-term cultivation; forest cover loss resulted in a decrease in SOC of up to $60 \%$. The grassland soil contained $45 \%$ more SOC than the cropland one. Soil organic carbon was mainly associated with the silt-size fraction; the most sensitive fractions to land-use change and forest cover depletion were POM followed by SOC associated with the silt and clay-sized fractions. Particulate organic matter can be used as an early indicator of SOC loss. The C lost from the clay and silt-sized fractions was thermally labile; therefore, the SOC stored in the more degraded forest soils was more recalcitrant (thermally resistant). Only the transformation of forest to agricultural land produced a similar loss of thermally stable $\mathrm{C}$ associated with the silt-sized fraction.
\end{abstract}

Keywords: Andosols, soil physical fractionation, forest cover depletion, thermal analyses, agriculture, soil organic matter

\section{Introduction}

Soils formed from volcanic materials (Andosols) contain the largest amount of soil organic carbon (SOC) among the mineral soil orders (Eswaran et al., 1993). However, forest cover loss decreases SOC which occurs in advance of complete deforestation when degraded forests are transformed into pasture, cropland and eroded areas (Cairns et al., 1995).

Fractionation of soils is based on the assumption that soil organic matter (SOM) which is associated with different

Correspondence: F. García-Oliva. E-mail: fgarcia@oikos.unam.mx Received July 2010; accepted after revision February 2011 Editor: Donald Davidson particle sizes also differs in chemical composition or function depending on degree of humification (Christensen, 2001). Land-use practices including cultivation can affect the quality and quantity of SOM associated with particles (Christensen, 2001), and may affect the distribution between particulate organic matter (POM) and SOM associated with minerals (Cambardella \& Elliott, 1993). Christensen (2001) proposes that the main effects of land use practices can be observed by changes in the distribution of SOC within particle-size classes. The size of POM which is strongly influenced by soil management has been used as an early indicator of trends in SOM in managed soils (Wander, 2004). Determination of particle-size fractions is useful in studying the effect of landuse change on soil carbon stocks, but few studies have been 
carried out to determine the effect of forest cover depletion on particle-size fractions, and even less so in volcanic soils.

Thermal stability of SOM is resistance to thermal oxidation during heating. Thermal properties have been used to assess SOM quality and decomposability (López et al., 2005; Plante et al., 2005). López et al. (2005) state that thermal analyses enable the distinction of labile and more recalcitrant components of physically separated SOM fractions. They found a correlation between fractions separated by thermal analyses and the results obtained from ${ }^{13} \mathrm{C}$ NMR analyses. Other authors have found consistent correlation between thermally separated fractions and results from pyrolysis (Leinweber et al., 1992). Plante et al. (2005) conclude that the thermal properties of clay-associated organic matter can be related to biological decomposability and that thermal techniques can be used to detect changes in SOM fractions as a consequence of land-use change, but there are few similar studies. The objective of this study was to determine the effect of land-use and forest cover depletion on the distribution of $\mathrm{C}$ within particle-size fractions in a volcanic soil. The thermal properties of the SOM associated with the silt and clay-size fractions were also investigated.

\section{Materials and methods}

\section{Site description}

The field site was in the Atécuaro catchment located between $19^{\circ} 33^{\prime}$ and $19^{\circ} 37^{\prime}$ North and between $101^{\circ} 09^{\prime}$ and $101^{\circ} 15^{\prime}$ West within the Cuitzeo Lake basin (Michoacán, Mexico), covering an area of $44.2 \mathrm{~km}^{2}$ with an altitude ranging from 2000 to $2700 \mathrm{~m}$ a.s.l. The climate is temperate subhumid, with a mean annual temperature of about $16.8{ }^{\circ} \mathrm{C}$ and mean annual precipitation of $844 \mathrm{~mm} / \mathrm{yr}$ which is concentrated between June and October. The predominant soil parent materials are Quaternary lavas and pyroclasts. Dominant soils in the catchment are Andosols and Cambisols (silty-loam and clayey-loam soils with a pH ca. 5.0; Instituto Nacional de Estadística, Geografía e Informática (INEGI), 1982).

Pine-oak forests are located mainly in the south and southeastern part of the catchment area between 2300 and $2500 \mathrm{~m}$ a.s.l. In 1975 pine and oak forests covered 17\% of the Cuitzeo basin and this had increased to $20 \%$ by 2000 López et al. (2006). This suggests that the actual vegetation cover and soil use have not changed, at the least in the last $40 \mathrm{yr}$. Maize is cultivated on the foothills and small valleys close to human settlements.

Six representative sites were selected in the southern part of the catchment with a northern aspect in a Silandic Andosol dominated area along a slope where different forest conditions and land-uses were well represented:

1. A grassland site that was previously used for agriculture and then abandoned ca. $30 \mathrm{yr}$ ago (GL),
2. Four forested sites under pine-oak vegetation with decreasing tree density downslope: pine-oak forest 1 (POF1), pine-oak forest 2 (POF2) and pine-oak forest 3 (POF3); note that a higher number indicates decreased forest cover; a fuelwood area (FW) suffered from a forest fire in 1998,

3. Recently abandoned agricultural land after long-term fallow (AL).

In April 2006, three composite soil samples (10 subsamples) were collected from the surface horizon $(0-$ $10 \mathrm{~cm}$ ) at each site using a cylindrical probe. The sampling area was $1200 \mathrm{~m}^{2}$ divided into three circular subplots of $400 \mathrm{~m}^{2}$; one composite sample was collected from each circular subplot. Soil samples were kept moist and stored at $4{ }^{\circ} \mathrm{C}$ prior to analysis because drying of volcanic-ash derived soils can affect soil physical properties (Nanzyo et al., 1993).

\section{Laboratory analyses}

Soil analysis. The SOC concentration was determined by the dry combustion method using a LECO analyser. Total $\mathrm{N}$ was determined using the Kjeldahl digestion-distillation method (Bremmer, 1965) and measured in a Bran Luebbe AA3 Autoanalyser.

Particle-size fractionation. The sonicator used was a Vibracell (Sonics \& Materials Inc., USA) with a maximum power output of $600 \mathrm{~W}$ and with a probe of $13 \mathrm{~mm}$ diameter. The sonicator was calibrated by determining the real power output calorimetrically, as described by Roscoe et al. (2000) and Oorts et al. (2005).

For fractionation $20 \mathrm{~g}$ of equivalent oven-dried soil were passed through a $2-\mathrm{mm}$ sieve and then transferred into a 150 $\mathrm{mL}$ glass beaker. Distilled water $(100 \mathrm{~mL})$ was added to give a ratio of soil to suspension of 1:5. The soil-water suspension was sonicated with the probe tip inserted $20 \mathrm{~mm}$ into the suspension. The minimum of energy required for complete dispersion was found by applying increasing amounts of ultrasonic energy before complete fractionation. From the results, it was decided to apply energy of $244 \mathrm{~J} / \mathrm{mL}$ to fractionate soil samples which seemed an appropriate compromise to minimize further breakdown of particles.

Coarse sand (2000-200 $\mu \mathrm{m})$ and fine sand $(200-50 \mu \mathrm{m})$ were separated from the sonicated suspension by wet sieving. Then the sieve fractions were collected and further separated into mineral and organic material (POM) through flotationdecantation in water. The remaining suspension containing only silt $(50-2 \mu \mathrm{m})$ and clay-sized particles $(<2 \mu \mathrm{m})$ were separated by centrifugation. Fractions were transferred to bottles for oven-drying. After fractionation the following size fractions were obtained: (a) clay, (b) silt, (c) fine sand, (d) coarse sand, and (e) POM separated from fine sand (POMFS) and (f) coarse sand (POM-CS). 
Thermal analyses. Thermal analyses were performed on the clay and silt-size fractions derived from the physical particlesize fractionation as described above. Thermogravimetry (TG) and differential thermal analysis (DTA) were performed simultaneously using a TA SDT-Q600 thermal analyser. For each sample, ca. $8 \mathrm{mg}$ of the soil fractions were placed in a platinum crucible and heated from room temperature to $800{ }^{\circ} \mathrm{C}$ at a heating rate of $10^{\circ} \mathrm{C} / \mathrm{min}$ in a synthetic air atmosphere $(100 \mathrm{~mL} / \mathrm{min})$. Three replicates per sample were run. Analyses of the TG traces and DTA peaks (exotherms represented as positive displacement) were performed using the instrument software.

Thermograms from Differential Scanning Calorimetry (DSC; data not shown) were simultaneously generated. The exothermic peaks detected in the DTA and DSC were comparable, indicating that the energy needed to degrade SOM was constant for the whole range of temperature and, therefore, it was justifiable to use both thermograms to detect peak temperatures related to SOM degradation.

Total weight loss associated with thermal decomposition of organic constituents between $200{ }^{\circ} \mathrm{C}$ and $600{ }^{\circ} \mathrm{C}$ was called Exotot following the nomenclature proposed by Dell'Abate 3 et al. (2002). Based on the first derivative of the TG (data not shown), Exotot was divided into Exol (the weight loss associated with the first exotherm as a proportion of Exotot), and Exo2 (the weight loss associated with the second exotherm as a proportion of Exotot). Each exotherm of the DTA thermograms corresponded to a weight loss detected in $\mathrm{TG}$, which allowed quantification of the different fractions involved in the reactions.

\section{Statistical analyses}

The effects of land use and forest cover depletion on bulk soil density, particle-size and thermogravimetric parameters were analysed by one-way ANOVA using Statistica 6 software

4 (StatSoft, 2000). A multiple comparison of means for each class variable was performed using Tukey's HDS test $(P<0.05)$.
The effect of forest cover depletion on soils was assessed through comparing results from the conserved forest site (POF1), the forest with limited loss of tree cover (POF2), the more intensely harvested forest (POF3) and the area that was subject to a recent forest fire (FW). Land-use effects were investigated by comparing the most conserved forest site (POF1) with the grassland area (GL) and the agricultural land (AL).

\section{Results}

\section{Soil properties}

Results for the upper soil layer $(0-10 \mathrm{~cm})$ are summarized in Table 1. SOC ranged from 35 to $130 \mathrm{~g} \mathrm{C} / \mathrm{kg}$. For forest sites, SOC decreased in the order POF1 $>$ POF2 $>$ FW $=$ POF3 (Table 2). Similarly, SOC concentrations decreased from the natural forest to agricultural land. Total $\mathrm{N}(\mathrm{Nt})$ varied between 2.6 and $8.3 \mathrm{~g} \mathrm{~N} / \mathrm{kg}$ and was significantly greater in POF1 and 2 than in the other two forest sites (FW and POF3; Table 1). Nt was also affected by land use and decreased from POF1 to the agricultural land following a pattern similar to $\mathrm{SOC}$. The $\mathrm{C} / \mathrm{N}$ ratio ranged from 10 to 22 and was significantly higher in the fuelwood area than in the other forest sites. Moreover, POF1 had a greater $\mathrm{C} / \mathrm{N}$ ratio than soils in the fallow area (GL).

\section{Soil organic $C$ in particle-size fractions}

Table 2 demonstrates the distribution of soil particle-size fractions as obtained using ultrasonic dispersion and also the $\mathrm{C}$ concentration associated with primary particles and POM. Total recovery of the initial amount of soil after fractionation ranged from 91 to $100 \%$.

The amount of clay and silt-sized particles ranged from 27 to $37 \%$ and from 44 to $49 \%$ respectively for all sites with no statistically different results according to forest soils or different land-uses. The amount of fine sand varied between 4 and $11 \%$ with corresponding values between 4 and $8 \%$ for coarse sand; all forest soils had similar values. Non-forested

Table 1 Soil characteristics of the upper horizons $(0-10 \mathrm{~cm})$ at the study sites

\begin{tabular}{llll}
\hline Site & SOC $(\mathrm{g} \mathrm{C} / \mathrm{kg})$ & $\mathrm{Nt}(\mathrm{g} \mathrm{N} / \mathrm{kg})$ & $\mathrm{C} / \mathrm{N}$ \\
\hline Grassland (GL) & $48.6(5.7) \mathrm{B}$ & $4.5(0.2) \mathrm{B}$ & $10.8(1.4) \mathrm{B}$ \\
Pine-oak forest 1 (POF1) & $35.0(4.2) \mathrm{C}$ & $2.8(0.0) \mathrm{C}$ & $12.5(1.5) \mathrm{AB}$ \\
Pine-oak forest 2 (POF2) & $130(11.5) \mathrm{Aa}$ & $8.3(1.1) \mathrm{Aa}$ & $15.9(1.4) \mathrm{Ab}$ \\
Fuelwood area (FW) & $82.3(10.2) \mathrm{b}$ & $2.6(0.4) \mathrm{b}$ & $13.5(1.5) \mathrm{b}$ \\
Agricultural land (AL) & $57.3(6.8) \mathrm{c}$ & $3.1(0.2) \mathrm{b}$ & $22.5(3.3) \mathrm{a}$ \\
Pine-oak forest 3 (POF3) & $50.5(8.1) \mathrm{c}$ & $16.3(2.0) \mathrm{b}$ \\
\hline
\end{tabular}

Effect of land use: GL, AL and POF1 (differences in capital letters). Effect of forest cover depletion: POF1, POF2, POF3 and FA (differences in small letters). Standard deviations are given in brackets. Different letters within the same column and effect indicate significant differences at $P<0.05$. 
Table 2 Particle-size fractions and organic carbon concentration within size-fractions from the 0 to 10 -cm soil layer

\begin{tabular}{|c|c|c|c|c|c|c|}
\hline Site & Clay-size & Silt-size & $\begin{array}{c}\text { Fine } \\
\text { sand-size }\end{array}$ & $\begin{array}{c}\text { Coarse } \\
\text { sand-size }\end{array}$ & $\begin{array}{c}\text { Fine-sand } \\
\text { particulate } \\
\text { organic matter }\end{array}$ & $\begin{array}{c}\text { Coarse-sand } \\
\text { particulate } \\
\text { organic matter }\end{array}$ \\
\hline \multicolumn{7}{|l|}{ Fraction size $(\%)$} \\
\hline Grassland & $34.8(3.8) \mathrm{A}$ & $48.6(2.1) \mathrm{A}$ & $9.5(3.0) \mathrm{A}$ & $4.7(0.8) \mathrm{B}$ & $1.9(1.2) \mathrm{A}$ & $0.5(0.3) \mathrm{B}$ \\
\hline Agricultural land & $28.9(1.3) \mathrm{A}$ & 44.9 (1.9) A & $11.0(0.7) \mathrm{A}$ & $7.8(0.6) \mathrm{A}$ & $1.2(0.4) \mathrm{A}$ & $0.7(0.3) \mathrm{B}$ \\
\hline Fuelwood area & $38.1(1.3) \mathrm{a}$ & $45.0(2.1) \mathrm{a}$ & $4.3(0.4) \mathrm{a}$ & $3.3(0.2) \mathrm{a}$ & $1.6(0.5) \mathrm{a}$ & $1.9(1.7) b$ \\
\hline Pine-oak forest 3 & $33.6(3.9)$ a & $47.6(3.7) \mathrm{a}$ & $7.3(1.0) \mathrm{a}$ & $5.3(0.6) \mathrm{a}$ & $1.2(0.5) \mathrm{a}$ & $1.0(0.2) \mathrm{b}$ \\
\hline \multicolumn{7}{|c|}{$\mathrm{C}$ concentration ( $\mathrm{g} \mathrm{C} / \mathrm{kg}$ soil fraction) } \\
\hline Grassland & $76.1(10) \mathrm{B}$ & $64.5(0.7) \mathrm{B}$ & $13.1(2.6) \mathrm{A}$ & 17.3 (4.1) B & $172(19) \mathrm{B}$ & $324(60) \mathrm{B}$ \\
\hline Agricultural land & $63.9(2.2) \mathrm{B}$ & $56.2(1.9) \mathrm{C}$ & $6.4(1.1) \mathrm{A}$ & $9.5(2.3) \mathrm{C}$ & $141(19) \mathrm{B}$ & $295(0.0) \mathrm{B}$ \\
\hline Pine-oak forest 1 & $155(3.5) \mathrm{Aa}$ & $136(9.8) \mathrm{Aa}$ & $12.5(2.2) \mathrm{Aa}$ & $14.9(0.1) \mathrm{Ab}$ & 380 (12) Aa & 422 (8.2) Aa \\
\hline \multicolumn{7}{|c|}{$\mathrm{C}$ distribution ( $\mathrm{g} \mathrm{C} / \mathrm{kg}$ soil) } \\
\hline Grassland & $27.6(3.6) \mathrm{B}$ & $32.7(0.4) \mathrm{B}$ & $0.7(0.1) \mathrm{A}$ & $1.2(0.5) \mathrm{B}$ & $1.7(0.5) \mathrm{B}$ & $3.2(0.6) \mathrm{B}$ \\
\hline Agricultural land & $18.6(1.9) \mathrm{B}$ & $23.4(1.7) \mathrm{C}$ & $0.9(0.4) \mathrm{A}$ & $0.8(0.2) \mathrm{B}$ & $2.7(1.3) \mathrm{B}$ & $2.0(1.0) \mathrm{B}$ \\
\hline Pine-oak forest 1 & $42.6(7.7) \mathrm{Aa}$ & 69.1(4.3) Aa & $0.6(0.1) \mathrm{Aa}$ & $5.1(1.7) \mathrm{Aa}$ & $17.1(1.6) \mathrm{Aa}$ & $22.2(7.8) \mathrm{Aa}$ \\
\hline Pine-oak forest 2 & $36.7(2.3) \mathrm{a}$ & $50.1(3.3) \mathrm{b}$ & $0.7(0.3) \mathrm{a}$ & $0.8(0.2) \mathrm{b}$ & $13.5(3.3) \mathrm{a}$ & $9.9(2.2) \mathrm{b}$ \\
\hline Fuelwood area & $22.8(0.2) \mathrm{b}$ & $38.3(0.9) \mathrm{c}$ & $0.6(0.1) \mathrm{a}$ & $1.0(0.2) \mathrm{b}$ & $5.5(1.3) \mathrm{b}$ & $5.1(2.2) \mathrm{b}$ \\
\hline Pine-oak forest 3 & $21.1(1.0) \mathrm{b}$ & $35.4(2.9) \mathrm{c}$ & $0.8(0.1) \mathrm{a}$ & $0.8(0.1) \mathrm{b}$ & $4.3(1.3) \mathrm{b}$ & $4.1(0.9) \mathrm{b}$ \\
\hline
\end{tabular}

Effect of land use: grassland, agricultural land and pino-oak forest 1 (differences in capital letters). Effect of forest cover depletion: pine-oak forest 1-3 and fuelwood area (differences in small letters). Standard deviations are given in brackets. Different letters within the same column and effect indicate significant differences at $P<0.05$.

areas had statistically greater amounts of fine sand particles and the AL had the highest amount of coarse sand particles. The amount of FS-POM was greater in the conserved forest than in the GL and AL. The amount of CS-POM was higher in the most conserved forest soil (POF1) than in the other forest sites.

In general, the $\mathrm{C}$ concentration of the particle-size fractions decreased in the order $\mathrm{POM}>$ clay $=$ silt $>$ sand. The $\mathrm{C}$ concentration of the POM fractions was similar for forest soils and was higher in the forest than in the other land-uses. The clay-associated $\mathrm{C}$ concentration ranged from 56 to $155 \mathrm{~g} \mathrm{C} / \mathrm{kg}$ fraction. The best conserved forest soils (POF1 and POF2) had higher concentrations than the two degraded forest soils (FW and POF3). Similarly, the forest soil had a higher $\mathrm{C}$ concentration than soil under the other two land uses. The concentration of $\mathrm{C}$ associated with the silt-size fraction (ranging from 56 to $136 \mathrm{~g} \mathrm{C} / \mathrm{kg}$ fraction) in soils decreased from natural to degraded forests, and among land uses decreased from the natural forest to the long-term fallow. The fine sand-associated $\mathrm{C}$ ranged from 6 to $14 \mathrm{~g} \mathrm{C} / \mathrm{kg}$ and no significant differences were found between sites. However, the coarse sand-associated $\mathrm{C}$ had the highest concentration in the FW, higher than the other forest soils. Among the land-uses, the forest had the highest $\mathrm{C}$ concentration for this particle-size fraction, followed by GL and AL.

The silt-associated $\mathrm{C}$ was the largest $\mathrm{C}$ pool for all the soils ( $49 \%$ of total soil $\mathrm{C}$, on average), followed by the $\mathrm{C}$ associated with the clay-sized fraction $(34 \%$ of total soil $\mathrm{C}$, on average). The $\mathrm{C}$ associated with the POM fractions accounted for $20-25 \%$ of the total soil $\mathrm{C}$ in the conserved forest soils (POF1 and 2; Figure 1), but was $<10 \%$ in the other land uses (GL and AL).

Soils in conserved forests (Pine oak forest 1 and 2) had in general a greater amount of $\mathrm{C}$ associated with the different particle-sizes; only the fine sand-sized fraction had similar values for all forest sites. Soils under different land-uses also had differences in the distribution of $\mathrm{C}$ associated with particle-size fractions. The proportions of $\mathrm{C}$ linked to the clay-size, coarse sand-size and POM fractions were significantly different under forest than in the GL and AL. Silt-associated C decreased in the order: forest $>\mathrm{GL}>\mathrm{AL}$.

\section{Thermal analyses}

The DTA traces of soil fractions showed an endothermic region between ambient temperatures and $150{ }^{\circ} \mathrm{C}$ because of water release and an exothermic region between 200 and 
Figure 1 The $\mathrm{C}$ distribution within particlesize fractions of volcanic soils under different land-uses in Central Mexico. (note: The $\mathrm{C}$ content of each fraction was calculated by taking total soil $\mathrm{C}$ as the sum of the $\mathrm{C}$ associated with all separate particle-size fractions, including POM fractions).

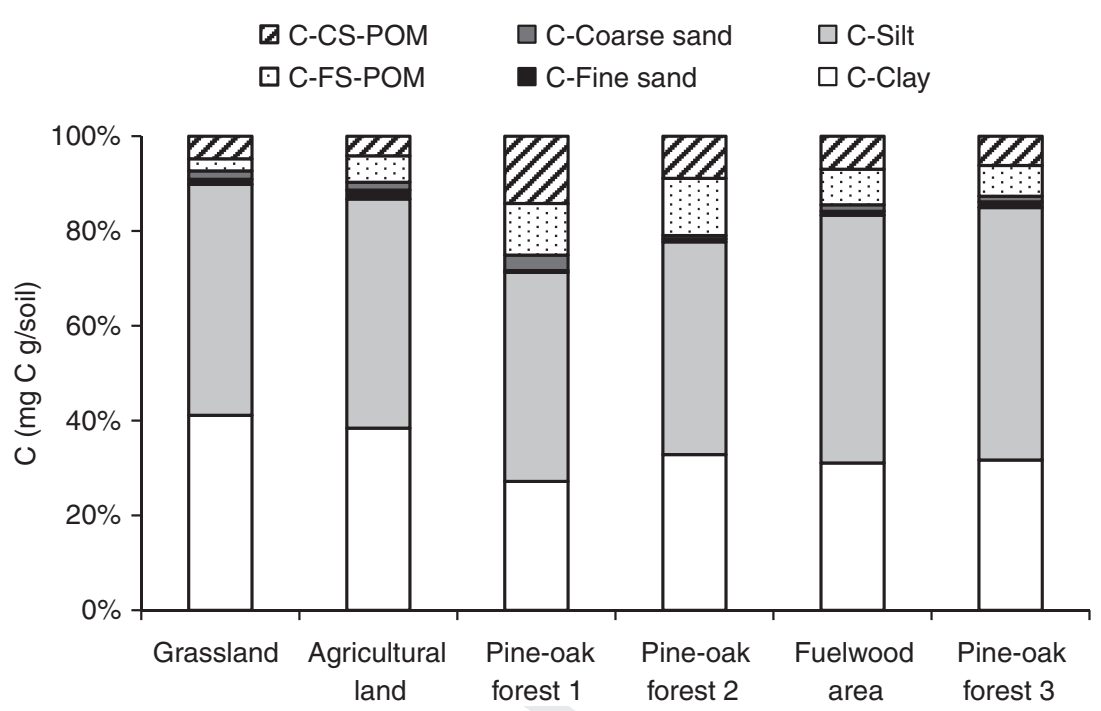

$600{ }^{\circ} \mathrm{C}$ (Figure 2). This region comprises two exothermic peaks because of the combustion and degradation of different SOM compounds. A smaller SOC concentration was associated with the smaller peak of the two detected exothermic ones and this was evident especially in the claysized fraction. The thermogravimetric results are presented in Table 3 .

Clay-sized fraction. The DTA traces for the clay-sized fraction had in all cases an exothermic peak at $320-327{ }^{\circ} \mathrm{C}$. Only in the GL did a second peak appear at $443{ }^{\circ} \mathrm{C}$, but for the other soils it was more a shoulder than a real peak. The Exotot varied from 21 to $35 \%$ and in general the Exol (10 $27 \%$ ) was larger than the Exo2 (7-11\%). For the forest soils, the POF1 had the highest Exotot and Exol followed by the POF2 and the other two forest soils (FW and POF3). The Exo2 was similar for all forest sites. Land-use affected the values of Exotot, Exo1 and Exo2. POF1 had the highest value for the three thermal variables. The fallow and agricultural land had a similar Exotot, but the GL had a higher Exo1 and Exo2 was higher in the AL than in the GL.

Silt-sized fraction. The DTA traces for the silt-size fraction had exothermic peaks at $333-342{ }^{\circ} \mathrm{C}$ and at $418-446{ }^{\circ} \mathrm{C}$. Forest sites had similar peak temperatures for the first exothermic peak $\left(341 \pm 1^{\circ} \mathrm{C}\right)$ and for the second the range of temperature differed by $8{ }^{\circ} \mathrm{C}$ between sites. For the different land uses the forest soil had significantly higher temperatures for the first exothermic peak and the GL for the second.

Results for Exotot (16.5-28.5\%) and Exol (6.7-13.4\%) have a similar pattern, decreasing in the following order among forest soils: POF $1>$ POF2 $>$ FW $=$ POF3. Exotot and Exo1 were largest for the forest soils followed by GL and finally AL. Exo2 (7-15\%) was in general larger than the
Exol and decreased in the order: POF1 $>$ POF2 $=\mathrm{FW}>$ POF3. The forest soil had the largest Exo2 among the landuses with AL having a larger value than for GL.

\section{Discussion}

\section{Effect of land-use on soil C pools}

In the Atécuaro sequence, SOC in the upper soil layer $(0-$ $10 \mathrm{~cm}$ ) varied by $70 \%$ between the most conserved forest soil (POF1) and AL. This accords with results of Cambardella \& Elliott (1992), Balesdent et al. (1998) and Chenu \& Plante (2006) who also found that the conversion from natural vegetation to agriculture leads to a depletion in SOC in different types of soils. Guo \& Gifford (2002) and Murty et al. (2002) report that the magnitude of the SOC loss may vary from 25 to $75 \%$, depending on the antecedent $\mathrm{C}$ pool, land use, management and climate. SOC losses are caused by a number of factors, including lower organic matter input to soil, increases in mineralization, soil erosion and leaching (Guo \& Gifford, 2002).

The soil under cropland contained $45 \%$ less $\mathrm{C}$ than the grassland soil. Grassland in the area includes shrub and herbaceous vegetation which resulted in a higher litter input compared with agricultural land where crop residues and harvested crops are removed. In grassland soils, much of the litter input is from root biomass (Tate et al., 2000). Overall, grassland sequesters more $\mathrm{C}$ than cropland (Guo \& Gifford, 2002).

The amount of clay- and silt-sized $\mathrm{C}$ fractions in the grassland and especially the cropland is lower than in the conserved forest site. The mean residence time (MRT) of $\mathrm{C}$ associated with clay- and silt-sized fractions is greater than that of the $\mathrm{C}$ associated with coarser sized particles (GarcíaOliva et al., 1994) as finer-sized separates are usually better aggregated to thus offer better protection from microbial 

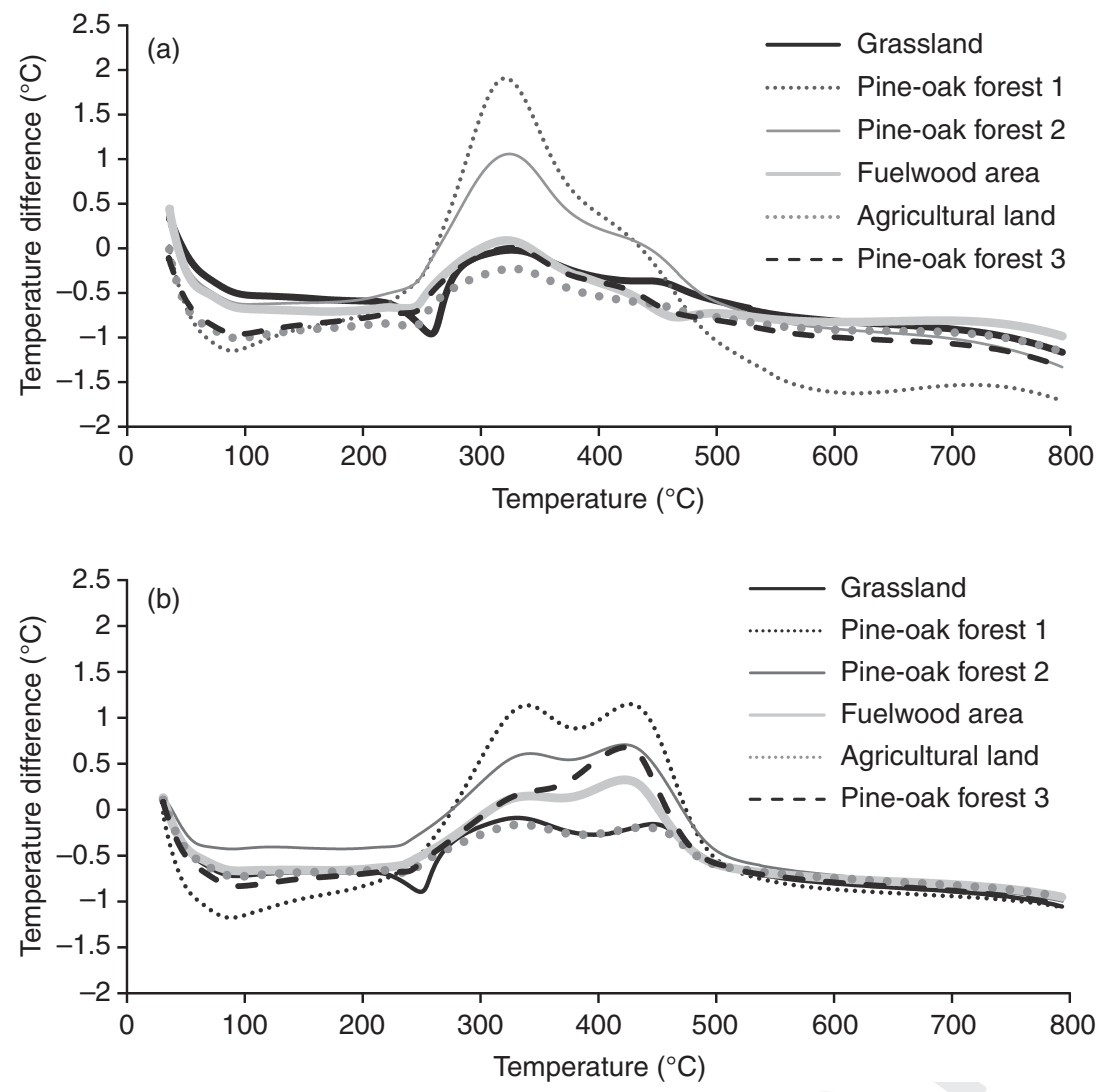

Figure 2 Differential thermal analysis of the: (a) clay-sized fraction and (b) silt-sized fraction of volcanic soils under different landuses in Central Mexico.

Table 3 Mean values of the thermogravimetric analyses of the clay- and silt-sized fractions

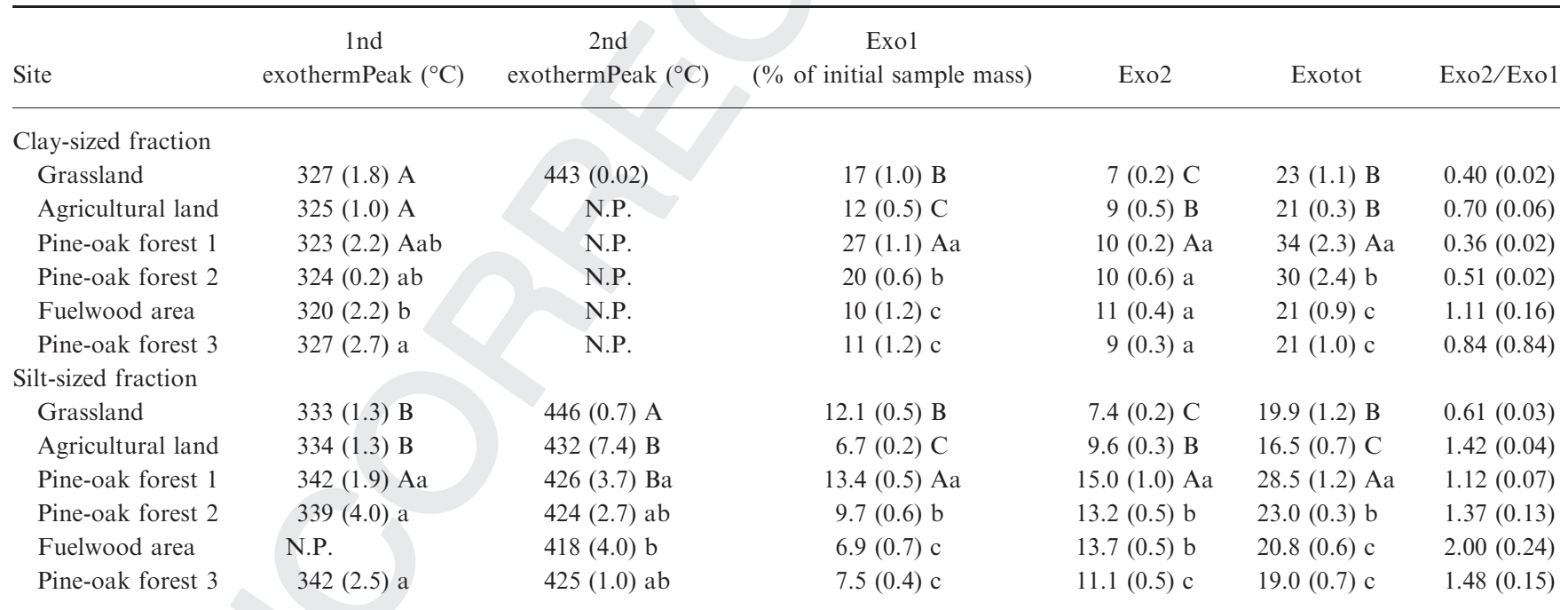

Exo1, Weight loss associated with the first exotherm; Exo2, Weight loss associated with the second exotherm; Exotot, Weight loss between 200 and $600{ }^{\circ} \mathrm{C}$. Effect of land use: grassland, agricultural land and pine-oak forest 1 (differences in capital letters). Effect of forest cover depletion: pine-oak forest 1-3 and fuelwood area (differences in small letters). Standard deviations are given in brackets. Different letters within the same column and effect indicate significant differences at $P<0.05$. N.P, no peak. N.d., not determined.

attack (van Veen \& Kuikman, 1990). Long-term agriculture and grassland had the effect of reducing the stable SOM pool of the soil where the $\mathrm{C}$ is very humified and contributes to long-term $\mathrm{C}$ sequestration.
The amount of $\mathrm{C}$ associated with sand fractions is very low and is a consequence of the $\mathrm{C}$ being in the form of finer particle-sizes which coat sand surfaces. C associated with POM fractions was on average $87 \%$ lower in the soils under 
the non-forested land-uses than under the conserved forest soil. The POM fractions had the highest decrease among the different size separates, which accords with the results of Balesdent et al. (1998) and Cambardella \& Elliott (1992). Chenu \& Plante (2006) report that free organic matter (FOM) was more depleted by cultivation than by claybound organic matter. This suggests a reduction in SOM renewal to thus constrain microbial activity and nutrient availability.

\section{Effect of forest cover depletion on soil C pools}

Soil organic carbon was from 37 to $61 \%$ lower in degraded forest sites compared with the best conserved area (POF1) which had the highest SOC content. Forest cover depletion had a significant impact on $\mathrm{C}$ associated with the clay- and silt-sized fractions, being $60 \%$ and $50 \%$ lower in the degraded forest (POF3) compared with the conserved forest (POF1).

The $\mathrm{C}$ concentration in the clay-sized fraction was higher for the silt-sized fraction of the conserved forest soils (POF1 and POF2) and lower or similar for the degraded forest soils (FW and POF3). These results suggest that $\mathrm{C}$ is lost preferentially from the clay-sized fraction with increasing forest cover loss. García-Oliva et al. (1994) report that the C silt-associated fraction was subject to a lower loss rate than the clay-associated $\mathrm{C}$ fraction in a tropical deciduous forest after conversion to pasture. This is because the clay-fraction was more enriched in new SOM because of microbial activity which decomposed faster than the silt-sized aggregate fraction (Gregorich et al., 1991).

The amount of POM recovered after particle-size fractionation in the degraded POF3 was $80 \%$ lower than in the conserved POF1. Therefore, POM seems to be the most sensitive fraction to detect degradation processes. Soil organic matter depletion in forest areas results from the decrease in vegetation density and biomass, and therefore there is a decreasing organic input to the soil which causes increases in soil temperature and thus mineralization.

\section{Thermal properties of the organic matter associated with the clay-and silt-sized fractions}

The exothermic parts of the DTA thermograms from the SOM fractions indicate a coincidence of two main exothermic processes, suggesting that SOC associated with different sizefractions have different thermal stabilities as reported by Leinweber et al. (1992), Dell'A Abate et al. (2002) and Plante et al. (2005). These reactions determine soil weight loss at different temperature steps as recorded on the TG curves (Dell'Abate et al., 2002).

Endothermic peaks above $150{ }^{\circ} \mathrm{C}$ are attributed to the dehydroxylation of clay minerals (Mackenzie \& Mitchell, 1972). Hutchinson (1974) proposes that the first endothermic peak $\left(240-250{ }^{\circ} \mathrm{C}\right)$ can correspond to cristobalite or allophone (only in andic soils) and the second $\left(464{ }^{\circ} \mathrm{C}\right)$ to kaolinite.

On the basis of all the samples, the first exotherm gives a maximum in the range $320-342{ }^{\circ} \mathrm{C}$ because of the decomposition of the more labile aliphatic compounds and decarboxylation of carboxylic groups (Leinweber et al., 1992). These results are consistent with the temperatures reported by Dell'Abate et al. (2002) for humic substances. The second exotherm indicates a maximum at ca. $418-446{ }^{\circ} \mathrm{C}$ because of the breakdown of aromatic structures (Leinweber et al., 1992) and to the decomposition of aliphatic biopolymers which are protected by clays or sesquioxides. This temperature range is in accordance with results of Dell'Abate et al. (2002) and López et al. (2005).

The relative proportions of Exo1 and Exo2 differed between the particle-size fractions. The DTA curves indicate that the clay-size fraction had a larger 'labile peak' than a 'recalcitrant one' whereas the silt-sized fraction had a larger 'recalcitrant peak', also found by García-Oliva et al. (1994). The silt-sized fraction may therefore contain more humified or recalcitrant SOM. The silt-sized fraction was more difficult to disrupt into finer particles (clay-size fraction) through sonication requiring an energy input of $>350 \mathrm{~J} / \mathrm{mL}$ which can be explained by the presence of 'pseudo-silt' (formed by very stable organo-mineral complexes), a common feature in volcanic ash derived soils. These results confirm that $\mathrm{C}$ sequestration takes place mainly within the silt-sized fraction.

To study the effect of land-use on organic matter quality, Plante et al. (2005) used results obtained from a conserved forest area as a reference and calculated ratios of other soil land uses to forest for TG masses, peak heights and areas. Based on this example, the POF1 soil was used in the present study as a reference (Table 4). The Exol ratios of the claysized fraction had the lowest values for degraded forest soils and long-term agricultural use to indicate that the $\mathrm{C}$ lost in this fraction was thermally labile, scarcely protected by inorganic colloids and poorly sorbed. In all cases $>50 \%$ of the clay associated $\mathrm{C}$ was related to Exol suggesting that half of the clay-associated $\mathrm{C}$ was vulnerable to loss. By contrast, the Exo2 ratios had values near to 1.0, indicating that the thermally stable $\mathrm{C}$ remained in the soil as a very stable, recalcitrant pool even after land-use change and long-term agricultural use.

The Exotot ratios of the silt-size fraction decreased significantly with increasing forest cover depletion. Based on the Exotot components (Exo1 and Exo2) up to 50\% of the $\mathrm{C}$ lost was thermally labile (Exo 1), while the thermally stable $\mathrm{C}$ (Exo 2) was lost more slowly. In the long-term fallow, the Exo1 ratio was similar to those from the most degraded forests, but in this case $\mathrm{C}$ was also lost from Exo2, indicating that long-term agricultural use may also deplete the thermally stable C. By contrast, the soil under long-term grassland (GL) was the only one that had a higher ratio for Exol than 
Table 4 Ratios of the thermogravimetric weight losses (Exotot, Exol and Exo2) of the grassland area, agricultural land, pine-oak forest 2, fuelwood area and pine-oak forest 3 compared with the selected reference site (pine-oak forest 1)

\begin{tabular}{|c|c|c|c|c|c|c|}
\hline \multirow[b]{2}{*}{ Site } & \multicolumn{3}{|c|}{ Clay-sized fraction } & \multicolumn{3}{|c|}{ Silt-sized fraction } \\
\hline & R-Exotot & R-Exo1 & R-Exo2 & R-Exotot & R-Exo1 & R-Exo2 \\
\hline Grassland (GL) & 0.68 & 0.63 & 0.70 & 0.70 & 0.90 & 0.49 \\
\hline Pine-oak forest 1 (POF1) & 0.61 & 0.46 & 0.90 & 0.58 & 0.50 & 0.64 \\
\hline Pine-oak forest 2 (POF2) & 0.86 & 0.76 & 1.08 & 0.81 & 0.72 & 0.88 \\
\hline
\end{tabular}

R-Exotot: ratio of the weight loss between 200 and $600{ }^{\circ} \mathrm{C}$ from the studied plots to the reference plot (POF1). R-Exo1: ratio of the weight loss associated with the first exotherm from the studied plots to the reference plot (POF1). Exo2: ratio of the weight loss associated with the second exotherm from the studied plots to the reference plot (POF1).

for Exo2, indicating the presence of a small pool of thermally stable C.

The grassland soil had the lowest values of $\mathrm{C}$ associated with Exo2, both in the clay and silt-sized fractions. This depletion in the $\mathrm{C}$ associated with Exo2 may be a consequence of loss of tree cover making the site more susceptible to erosion (Kimble et al., 2000).

\section{Conclusions}

The change of forested land to other uses caused the depletion of labile SOM, thus lowering SOC in the upper soil layers. The SOC in the conserved forest soil was $70 \%$ greater than the agricultural soil and $60 \%$ greater than the soil under the most degraded forest. POM was the most sensitive fraction to land-use change and declined by almost $90 \%$, followed by the silt- and clay-sized fractions which had 53$66 \%$ and $35-56 \%$ less $\mathrm{C}$ after the conversion of forest to cropland and grassland, respectively. Forest cover loss could be the reason for the decrease in POM $(<80 \%)$, and clay $(<60 \%)$ and silt $(<50 \%)$ sized fractions.

The $\mathrm{C}$ lost from the clay-sized fraction as a result of changes in land-use and forest cover depletion totalled ca. $50 \%$ and can be attributed to the thermally labile fraction (aliphatic $\mathrm{C}$ or weakly sorbed). At the forest sites the $\mathrm{C}$ associated with the silt-sized fraction was also lost (the thermal labile fraction). Therefore, the SOM stored in the more degraded forest soils was more recalcitrant (aromatic C or protected by inorganic colloids) as only this $\mathrm{C}$ remained in the soil. The transformation of forest to agricultural land also produced a loss of $\mathrm{C}$ from the more thermally stable siltfraction.

The results demonstrate that thermogravimetry and differential thermal analysis of the clay and silt-sized fractions are useful techniques for detecting changes in SOM as a consequence of changes in land-use management, and thus allows determination of the extent to which soil has been degraded.

\section{Acknowledgements}

The authors gratefully acknowledge the help of two anonymous reviewers, R. Velázquez-Durán for his assistance in fieldwork, H. Ferreira and A. Valencia for their technical assistance. In addition, we thank the European Union for the support of the REVOLSO Project (INCO Program, ICA4CT-2001-10052), the Spanish Ministry of Education and Science and UNAM (SDEI-PTID-02) that partially financed the Project.

\section{References}

Balesdent, J., Besnard, E., Arrouays, D. \& Chenu, C. 1998. The dynamics of carbon in particle-size fractions of soil in a forestcultivation sequence. Plant and Soil, 201, 49-57.

Bremmer, J.M. 1965. Total nitrogen. In: Methods of soil analysis Part 2 (ed. C.A. Black), pp. 1149-1178. American Society of Agronomy, Madison.

Cairns, M.A., Dirzo, R. \& Zadroga, F. 1995. Forests of Mexico: a diminishing resource. Journal of Forestry, 93, 21-24.

Cambardella, C.A. \& Elliott, E.T. 1992. Particulate soil organicmatter changes across a grassland cultivation sequence. Soil Science Society of America Journal, 56, 777-783.

Cambardella, C.A. \& Elliott, E.T. 1993. Carbon and nitrogen in aggregates from cultivated and native grassland soils. Soil Science Society of America Journal, 57, 1071-1076.

Chenu, C. \& Plante, A.F. 2006. Clay-size organo-mineral complexes in a cultivation chronosequence: revisiting the concept of the "primary organo-mineral complex". European Journal of Soil Science, 57, 596-607.

Christensen, B.T. 2001. Physical fractionation of soil and structural and functional complexity in organic matter turnover. European Journal of Soil Science, 52, 345-353.

Dell'Abate, M.T., Benedetti, A., Trinchera, A. \& Dazzi, C. 2002. Humic substances along the profile of two Typic Haploxerert. Geoderma, 107, 281-296.

Eswaran, H., Vandenberg, E. \& Reich, P. 1993. Organic carbon in soils of the world. Soil Science Society of America Journal, 57, 192-194. 
García-Oliva, F., Casar, I., Morales, P. \& Maass, J.M. 1994. Forestto pasture conversion influences on soil organic carbon dynamics in a tropical deciduous forest. Oecologia, 99, 392-396.

Gregorich, E.G., Voroney, R.P. \& Kachanoski, R.G. 1991. Turnover of carbon through the microbial biomass in soils with different textures. Soil Biology and Biochemistry, 23, 799-805.

Guo, L.B. \& Gifford, R.M. 2002. Soil carbon stocks and land use changes: a meta analysis. Global Change Biology, 8, 345-360.

Hutchinson, C.S. 1974. Laboratory handbook of petrographic techniques. John Wiley \& Sons, London, UK.

Instituto Nacional de Estadística, Geografía e Informática (INEGI). 1982. Carta edafológica E14A23, escala 1: 50 0000. INEGI Aguascalientes, Mexico.

Kimble, J.M., Ping, C.L., Summer, M.E. \& Wilding, L.P. 2000. Andisols. In: Handbook of soil science (ed. M.E. Sumner), pp. E209-E224. CRC Press, Boca Raton.

Leinweber, P., Schulten, H.R. \& Horte, C. 1992. Differential thermal analysis, thermogravimetry and pyrolisis-field ionisation mass spectrometry of soil organic matter in particle-size fractions and bulk soil samples. Thermochemica Acta, 194, 175-187.

López, E., Sohi, S., Gaunt, J.L. \& Manning, D.A.C. 2005. Use of thermogravimetry-differential scanning calorimetry to characterize modelable soil organic matter fractions. Soil Science Society of America Journal, 69, 136-140.

López, E., Bocco, G., Mendoza, M., Velázquez, A. \& AguirreRivera, J.R. 2006. Peasant emigration and land-use change at the watershed level: a GIS-based approach in Central Mexico. Agricultural System, 90, 62-78.

Mackenzie, R.C. \& Mitchell, B.D. 1972. Soils. In: Differential thermal analysis. Vol. II. Applications (ed. R.C. Mackenzie), pp. 267-297. Academic Press, London, UK.
Murty, D., Kirschbaum, M.U.F., McMurtrie, R.E. \& McGilvray, H. 2002. Does conversion of forest to agricultural land change soil carbon and nitrogen? a review of the literature. Global Change Biology, 8, 105-123.

Nanzyo, M., Dahlgren, R. \& Shoji, S. 1993. Physical characteristics of volcanic ash soils. In: Volcanic ash soils, genesis, properties and utilization (eds S. Shoji, M. Nanzyo \& R. Dahlgren), pp. 189-207. ElSevier Science Publ, Amsterdam, the Netherlands.

Oorts, K., Vanlauwe, B., Recous, S. \& Merckx, R. 2005. Redistribution of particulate organic matter during ultrasonic dispersion of highly weathered soils. European Journal of Soil Science, 56, 77-91.

Plante, A.F., Pernes, M. \& Chenu, C. 2005. Changes in clayassociated organic matter quality in a $\mathrm{C}$ depletion sequence as measured by differential thermal analyses. Geoderma, 129, 186-199.

Roscoe, R., Buurman, P. \& Velthorst, E.J. 2000. Disruption of soil aggregates by varied amounts of ultrasonic energy in fractionation of organic matter of a clay Latosol: carbon, nitrogen and $\delta^{13} \mathrm{C}$ distribution in particle-size fractions. European Journal of Soil Science, 51, 445-454.

Tate, K.R., Scott, N.A., Ross, D.J., Parshotam, A. \& Claydon, J.J. 2000. Plant effects on soil carbon storage and turnover in a montane beech (Nothofagus) forest and adjacent tussock grassland in New Zeland. Australian Journal of Soil Research, 38, 685-698.

van Veen, J.A. \& Kuikman, P.J. 1990. Soil structural aspects of decomposition of organic matter by microorganism. Biogeochemistry, 11, 213-233.

Wander, M. 2004. Soil organic matter fractions and their relevance to soil function. In: Soil organic matter in sustainable agriculture (eds M. Magdoff \& R.R. Weil), pp. 67-102. CRC Press, Boca Raton. 


\section{Author Query Form}

\section{Journal: $\quad$ SUM}

\section{Article: $\quad 341$}

Dear Author,

During the copy-editing of your paper, the following queries arose. Please respond to these by marking up your proofs with the necessary changes/additions. Please write your answers on the query sheet if there is insufficient space on the page proofs. Please write clearly and follow the conventions shown on the attached corrections sheet. If returning the proof by fax do not write too close to the paper's edge. Please remember that illegible mark-ups may delay publication.

Many thanks for your assistance.

\begin{tabular}{|l|l|l|}
\hline Query reference & Query & Remarks \\
\hline 1 & AUTHOR: Please check that authors and their affiliations are correct. & \\
\hline 2 & $\begin{array}{l}\text { AUTHOR: Please check all units as they have been changed to match } \\
\text { journal style. }\end{array}$ & \\
\hline 3 & $\begin{array}{l}\text { AUTHOR: Dell'Abate et al. (2002) has been changed to Dell'Abate et al. } \\
(2002) \text { so that this citation matches the Reference List. Please confirm that } \\
\text { this is correct. }\end{array}$ & \\
\hline 4 & $\begin{array}{l}\text { AUTHOR: StatSoft, 2000 has not been included in the Reference List, } \\
\text { please supply full publication details. }\end{array}$ & \\
\hline 5 & $\begin{array}{l}\text { AUTHOR: Please check all your entries in Tables 1-4 and ensure that they } \\
\text { have been correctly presented. }\end{array}$ & \\
\hline
\end{tabular}




\section{Please correct and return this set}

Please use the proof correction marks shown below for all alterations and corrections. If you wish to return your proof by fax you should ensure that all amendments are written clearly in dark ink and are made well within the page margins.

\begin{tabular}{|c|c|c|}
\hline Instruction to printer & Textual mark & Marginal mark \\
\hline Leave unchanged & ... under matter to remain & ( ) \\
\hline $\begin{array}{l}\text { Insert in text the matter } \\
\text { indicated in the margin }\end{array}$ & $h$ & $\begin{array}{l}\text { New matter followed by } \\
h \text { or } h \otimes\end{array}$ \\
\hline Delete & $\begin{array}{l}\text { I through single character, rule or underline } \\
\text { or }\end{array}$ & $\sigma$ or $\sigma(x)$ \\
\hline $\begin{array}{l}\text { Substitute character or } \\
\text { substitute part of one or } \\
\text { more word(s) }\end{array}$ & I through letter or & $\begin{array}{l}\text { new character / or } \\
\text { new characters / }\end{array}$ \\
\hline Change to italics & — under matter to be changed & $\leftarrow$ \\
\hline Change to capitals & $\equiv$ under matter to be changed & $\equiv$ \\
\hline Change to small capitals & $=$ under matter to be changed & $=$ \\
\hline Change to bold type & $\sim$ under matter to be changed & $\sim$ \\
\hline Change to bold italic & $\bar{\sim}$ under matter to be changed & $\underline{s i n}$ \\
\hline Change to lower case & Encircle matter to be changed & $\Rightarrow$ \\
\hline Change italic to upright type & (As above) & \\
\hline Change bold to non-bold type & (As above) & \\
\hline Insert 'superior' character & $\begin{array}{l}/ \text { through character or } \\
K \text { where required }\end{array}$ & $\begin{array}{l}y^{\prime} \text { or } y \\
\text { under character } \\
\text { e.g. } y^{2} \text { or } y^{2}\end{array}$ \\
\hline Insert 'inferior' character & (As above) & $\begin{array}{l}\lambda \\
\text { over character } \\
\text { e.g. } \hat{\Sigma}\end{array}$ \\
\hline Insert full stop & (As above) & $\odot$ \\
\hline Insert comma & (As above) & , \\
\hline Insert single quotation marks & (As above) & $\begin{array}{l}\dot{y} \text { or } \dot{x} \text { and/or } \\
\dot{y} \text { or } \dot{y}\end{array}$ \\
\hline Insert double quotation marks & (As above) & $\begin{array}{l}\ddot{y} \text { or } \ddot{y} \text { and/or } \\
\ddot{y} \text { or } \ddot{y}\end{array}$ \\
\hline Insert hyphen & (As above) & 1 \\
\hline Start new paragraph & 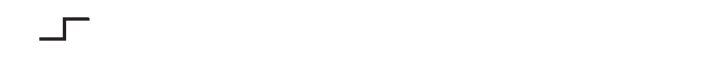 &  \\
\hline No new paragraph & $\infty$ & $\omega$ \\
\hline Transpose & $\sqcup$ & $\sqcup$ \\
\hline Close up & linking $\bigcirc$ characters & \\
\hline $\begin{array}{l}\text { Insert or substitute space } \\
\text { between characters or words }\end{array}$ & $\begin{array}{l}\text { I through character or } \\
\Lambda \text { where required }\end{array}$ & \\
\hline $\begin{array}{l}\text { Reduce space between } \\
\text { characters or words }\end{array}$ & $\begin{array}{l}\text { between characters or } \\
\text { words affected }\end{array}$ & $\uparrow$ \\
\hline
\end{tabular}

